\title{
PENGARUH MODEL PEMBELAJARAN KOOPERATIF TIPE SNOWBALL THROWING BERBANTUAN LAGU DAERAH TERHADAP HASIL BELAJAR IPA
}

\author{
I Wyn Sumerta ${ }^{1}$, Dw. Nyoman Sudana ${ }^{2}$ \\ 1,2 Jurusan Pendidikan Guru Sekolah Dasar, FIP \\ Universitas Pendidikan Ganesha \\ Singaraja, Indonesia \\ e-mail: sumertaiwayan25@gmail.com ${ }^{1}$, dewanyoman.sudana@undiksha.ac.id ${ }^{2}$
}

\begin{abstract}
Abstrak
Penelitian ini bertujuan untuk mengetahui perbedaan hasil belajar IPA antara siswa yang dibelajarkan dengan model pembelajaran kooperatif tipe snowball throwing berbantuan lagu daerah dan siswa yang dibelajarkan dengan pembelajaran konvensional pada kelas $\mathrm{V}$ di Gugus VI Kecamatan Kintamani Kabupaten Bangli Tahun Pelajaran 2017/2018. Jenis penelitian termasuk eksperimen semu dengan desain nonequivalent post-test only control group design. Populasi penelitian ini seluruh siswa kelas $V$ yang berjumlah 109 orang dan sampel penelitian yang berjumlah 50 orang. Data hasil belajar IPA siswa dikumpulkan dengan metode tes dengan tes hasil belajar IPA dan bentuk tes objektif pililihan ganda. Data yang dikumpulkan dianalisis menggunakan uji-t dengan program SPSS 21.0 for windows. Skor rata-rata kelompok eksperimen adalah 19,82 dan skor rata-rata kelompok kontrol adalah 16,09. Analisis data menggunakan uji-t diperoleh $t_{\text {hit }}=3,228>t_{\text {tab }}=2,000$ dan nilai sig $0,02<0,05$. Sehingga dapat disimpulkan bahwa penerapan model pembelajaran kooperatif tipe snowball throwing berbantuan lagu daerah berpengaruh positif terhadap hasil belajar IPA.
\end{abstract}

Kata kunci: Hasil Belajar IPA, Snowball Throwing

\begin{abstract}
This study aims to find out the differences between students outcome in learning IPA which involved in cooperative learning model typed snowball throwing combined by the regional songs and the students who involved in conventional learning at grade five students in Gugus VI Kintamani Subdistrict Bangli Regency in accademic year 2017/2018. This research was quasi-experimental research and used nonequivalent post-test only control group design as the design of this study. The population was all students at grade five in Gugus VI Kintamani numbered 109 students. The sample was the students at grade five in SDN Serai and SDN Awan in numbered 50 students. The result of students in learning IPA was collected by test method of the result of students learning in IPA. The collecting data was analyzed by using the t-test that assisted by SPSS 21.0 for windows. The average score of the experimental group was 19.82 and the mean score of the control group was 16.09 . The data analysis was using $\mathrm{t}$-test that obtained $\mathrm{t}_{\text {hit }}=3.228>\mathrm{t}_{\mathrm{tab}}=2.00$ and sig value $0.02<0.05$. So it can be concluded that the implementation of cooperative learning model typed snowball throwing combined by regional songs have a positive effect on the results of learning IPA.
\end{abstract}

Keywords: Outcomes IPA, Snowball Throwing

Jurnal IImiah Pendidikan Profesi Guru | 50 


\section{Pendahuluan}

Pada dasarnya pedidikan akan tidak pernah selesai dari masa ke masa di kehidupan manusia dengan adanya pendidikan manusia dapat bersaing diera globalisasi ini serta mampu mengambangkan sumber daya manusia. Sedangkan Undang-undang No. 20 Tahun 2003 tentang Sistem Pendidikan Nasional menyatakan, Pendidikan adalah usaha sadar dan terencana untuk mewujudkan suasana belajar dan proses pembelajaran agar peserta didik secara aktif mengembangkan potensi dirinya untuk memiliki kekuatan spiritual keagamaan, pengendalian diri, kepribadian, kecerdasan, akhlak mulia, serta keterampilan yang diperlukan dirinya, masnyarakat, bangsa, dan Negara. Sesuai dengan isi undang-undang tersebut maka pendidikan merupakan salah satu kebutuhan bagi manusia yang mencakup banyak aspek dikehidupannya. Masalah pendidikan yang dihadapi Indonesia saat ini adalah bagaimana meningkat kualitas pendidikan. Saat ini pemerintah sudah banyak melakukan upaya untuk meningkatkan kualitas pendidikan khususnya di Sekolah Dasar. Sekolah Dasar sebagai titik awal pendidikan formal di Indonesia memiliki pengaruh besar sebagai pondasi pengetahuan untuk kelanjutan pendidikan sesorang. Sudah seharusnya Sekolah Dasar dapat memberikan pondasi yang kokoh bagi siswanya. Pendidikan di jenjang Sekolah Dasar telah dirancang beberapa mata pelajaran yang wajib diberikan kepada siswa, salah satunya yaitu mata pelajaran IImu Pengetahuan Alam.

IPA merupakan singkatan dari IImu Pengetahuan Alam (Natural Science) dalam Bahasa Indonesia istilah Science sering digunakan penulis telah disesuikan dengan Bahasa Indonesia yaitu Sains. Pembelajaran IPA sangat berperan dalam proses pendidikan dan juga perkembangan teknologi. IPA adalah IImu pengetahuan yang mempelajari gejala-gejala alam yang diamati melalui pengumpulan data dan diskusi sehingga mendapatkan suatu kesimpulan. Sudana, dkk, (2010:2) menyatakan IPA berasal dari bahasa inggris science perkataan singkat dari Natural artinya alamiah, berhubungan dengan alam atau bersakutan paut dengan alam. Science secara harfifah dapat disebut sebagai ilmu tentang alam ini, ilmu yang mempelajari peristiwa-peristiwa atau gejala-gejala yang terjadi di alam.

Berdasarkan pencatatan dokumen hasil belajar IPA pada siswa kelas V di SDN Gugus VI Kecamatan Kintamani Kabupaten Bangli Tahun Pelajaran 2017/2018 109 siswa, dengan siswa yang belum mencapai KKM 56\% dan siswa yang sudah mencapai KKM 44\%. Jadi dapat disimpulkan siswa yang belum mencapai KKM lebih tinggi dari pada siswa yang sudah mencapai KKM sehingga pembelajaran IPA belum optimal. Berdasarkan hasil wawancara dan pengamatan yang dilakukan oleh peneliti, terdapat beberapa faktor yang mempengaruhi hasil belajar yaitu:(1) guru menyajikan materi lebih sering menggunakan metode ceramah, (2) pada saat proses pembelajaran guru kurang memperhatikan siswa yang ribut, (3) guru jarang menggunakan media dalam proses pembelajaran padahal media pembelajaran sudah disediakan di Sekolah dan (4) karena keterbatasan waktu guru jarang menggunakan model pembelajaran. Sehingga pelajaran IPA di gugus VI Kintamani belum optimal.

Berdasarkan Permendikbud No. 19 Tahun 2005 pada pasal 19 ayat 1 disebutkan, Proses pembelajaran diselenggarakan secara interatif, inspiratif, menyengkan, menantang, memotivasi peserta didik untuk berpatisipasi aktif, serta memberikan ruang yang cukup bagi prakarsa, kreativitas dan kemandirian sesuai bakat, minat, dan perkembangan fisik serta psikologi peserta didik. Pembelajaran yang demikan dapat diwujudkan dengan penerapan model pembelajaran kooperatif. Rusman (2011:203) menyatakan bahwa "pembelajaran kooperatif merupakan bentuk pembelajaran dengan cara siswa belajar dan bekerja dalam kelompok - kelompok kecil secara kolaboratif yang anggotanya terdiri dari empat sampai enam orang dengan setruktur kelompok yang bersifat hiterogen". Dalam penelitian ini model kooperatif yang dipilih model pembelajaran kooperatif tipe snowball throwing. Pembelajaran kooperatif tipe snowball throwing adalah merupakan model pemmbelajaran kooperatif yang pelaksananya mengajak siswa dalam proses pembelajaranya sehingga semua siswa akan aktif dalam melaksankan diskusi atau berkerja sama dalam membuat soal dan menjawab soal yang sudah merka dapatkan. Peran guru hanya memberi arahan awal mengenai topik pembelajaran yang akan diberikan dan selanjutnya menjaga ketertiban kelas dalam 
pelaksanaan pembelajaran. Shoimin (2014:174) menyatakan model pembelajaran snowball throwing merupakan pengembangan dari model pembelajaran diskusi dan merupakan bagian dari model pembelajran kooperatif. Hanya saja, pada model ini, kegiatan belajar diatur sedemikian rupa sehingga proses belajar mengajar dapat berlangsung dengan lebih menyenangkan.

Untuk mengatasi permasalahan di atas, dapat diatasi dengan menerapkan model pembelajaran Snowball Throwing. Snowball Throwing dapat diartikan sebagai metode pembelajaran yang menggunakan bola pertanyaan dari kertas yang digulung bulat berbentuk bola kemudian dilemparkan secara bergiliran di antara sesama anggota kelompok. Snowball Throwing merupakan salah satu tipe pembelajaran kooperatif yang dirancang untuk mempengaruhi pola interaksi siswa dan memiliki tujuan untuk meningkatkan penguasaan akademik. Dalam Snowball Throwing, guru berusaha memberikan kesempatan kepada siswa untuk mengembangkan keterampilan menyimpulkan isi berita atau informasi yang mereka peroleh. Guru juga memberikan pengalaman kepada siswa melalui pembelajaran terpadu dengan menggunakan proses yang saling berkaitan dalam situasi dan konteks komunikasi alamiah baik sosial, sains, hitungan, dan lingkungan pergaulan.

Berdasarkan uraian di atas maka diperlukan model pembelajaran yang dapat meningkatkan hasil belajar siswa. Salah satu model pembelajaran yang dapat digunakan untuk meningkatkan hasil belajar siswa adalah model pembelajaran kooperatif tipe Snowball Throwing. Model pembelajaran kooperatif tipe Snowball Throwing merupakan model pembelajaran yang dalam pelaksanaannya dengan pantauan guru siswa bela-jar dalam kelompok dan saling bekerja sama untuk menguasai materi pelajaran (Purbowo dkk, 2012:22).

Menurut Slavin (2008) bahwa: Pembelajaran koopertif adalah pembelajaran dimana siswa belajar secara kolompok. Pada pembelajaran ini siswa dikelompokkan. Tiap-tiap kelompok terdiri dari 4 atau 5 orang siswa. Anggota kelompok harus heterogen baik kognitif, jenis kelamin, suku, dan agama. Belajar dan bekerja secara kolabolaratif, dengan struktur kelompok yang heterogen. Kunandar (2007) menyatakan bahwa pembelajaran kooperatif adalah pembelajaran yang secara sadar dan sengaja mengembangkan interaksi yang saling asuh antar siswa untuk menghindari ketersinggungan dan kesalah pahaman yang akan dapat menimbulkan permusuhan. Selanjutnya Sanjaya (2007) menyatakan bahwa prosedur pembelajaran kooperatif pada prinsipnya terdiri atas, yaitu: (1) penjelasan materi, (2) belajar dalam kelompok, (3) penilaian, dan (4) pengakuan tim. Untuk lebih jelasnya dapat dilihat dalam langkah-langkah berikut: Membagi siswa dalam 5 kelompok dengan anggota kelompok yang heterogen baik dari segi prestasi, jenis kelamin, dan suku, yang pembagian kelompoknya dilakukan guru secara acak.

Salah satu tipe pembelajaran kooperatif adalah dengan tipe snowball throwing. Zaini, dkk (2007) strategi ini digunakan untuk mendapatkan jawaban yang dihasilkan dari diskusi siswa secara bertingkat. Dimulai dari kelompok kecil kemudian dilanjutkan dengan kelompok yang lebih besar sehingga pada akhirnya akan memunculkan dua atau tiga jawaban yang telah disepakati oleh siswa secara berkolompok. Strategi ini akan berjalan dengan baik jika materi yang dipelajari menuntut siswa yang berpikir analisis bahkan mungkin sintetis. Materi-materi yang bersifat faktual, yang jawabannya sudah ada di dalam buku teks mungkin tidak tepat diajarkan dengan strategi ini. Zaini dkk, (2007) mengemukakan langkah-langkah metode snowball throwing sebagai berikut: Sampaikan pokok meteri yang akan diajarkan. (1). Mintalah siswa untuk menjawab secara berpasangan (2). Setelah siswa yang bekerja berpasangan tadi mendapatkan jawaban, pasangan tadi digabungkan dengan pasangan di sampingnya. Dengan ini terbentuk anggota kelompok berjumlah empat orang. (3). Kelompok berempat ini mengerjakan tugas yang sama seperti dalam kelompok dua orang. Tugas ini dapat dilakukan dengan membandingkan jawaban kelompok dua orang dengan kelompok yang lain. Dalam langkah ini perlu ditegaskan bahwa jawaban kedua kelompok ini harus disepakati oleh semua anggota kelompok baru. (4). Setelah kelompok berempat ini selesai mengerjakan tugas, setiap kelompok digabungkan dengan satu kelompok yang lain. Dengan ini muncul kelompok yang baru yang anggotanya delapan 
orang. (5). Yang dikerjakan oleh kelompok baru ini sama dengan tugas pada langkah keempat di atas. Langkah ini baru dilanjutkan sesuai dengan jumlah siswa atau waktu yang tersedia. (6). Masing-masing kelompok diminta menyampaikan hasilnya di muka kelas.h. Pengajar akan membandingkan jawaban dari masing-masing kelompok kemudian memberikan ulasan-ulasan (7). dan penjelasan secukupnya sebagai klarifikasi dari jawaban siswa.

Tim Pustaka Yustisia (2007) juga menjelaskan langkah-langkah pembelajaran kooperatif tipe snowball trowing yaitu, sebagai berikut (1). Guru menyampaikan materi yang akan disajikan, (2). Guru membentuk kelompok-kelompok dan memangil masing-masing ketua kelompok untuk memberikan penjelasan tentang materi (3). Masing-masing ketua kelompok kembali ke kelompoknya masing-masing, kemudian menjelaskan materi yang disampaikan oleh guru kepada teman-temannya. (4). Kemudian masing-masing siswa diberikan satu lembar kertas kerja, untuk menuliskan satu pertanyaan apa saja yang menyangkut materi yang sudah dijelaskan oleh ketua kelompok. (5). Kemudian kertas tersebut dibuat seperti bola dan dilepar dari satu siswa kesiswa yang lain selama 15 menit. (6). Setelah satu siswa mendapat bola/ pertanyaan diberikan kepada siswa untuk menjawab pertanyaan yang tertulis dalam kertas berbentuk bola tersebut secara bergantian. (7). Evaluasi, (8). Penutup

Hasil penelitian yang televan dengan model pembelajaran kooperatif tipe Snowball Throwingadalah penelitian yang dilakukan oleh (Purbowo dkk, 2012:25) yang menyatakan pembelajaran Snowball Throwing merupakan pembelajaran yang efektif sehingga dapat digunakan sebagai salah satu alternatif dalam mengefektifkan pembelajaran matematika pada materi lingkaran. Selain itu, penelitian yang juga dilakukan oleh (Akhiriyah, 2011:216) menyatakan bahwa pembelajaran Snowball Throwing dapat meningkatkan aktifitas siswa dalam pembelajaran IPS dan juga dapat meningkatkan hasil belajar IPS.

Dalam pembelajaran Snowball Throwing siswa diajak untuk berkomunikasi dengan baik dengan kelompoknya, hal ini terlihat pada saat menjawab pertanyaan yang didapat dilakukan dengan berdiskusi kelompok. Dari uraian di atas dapat disimpulkan bahwa pembelajaran Snowball Throwing tidak hanya meningkatkan kemampuan siswa dari segi akademik tetapi juga mengembangkan keterampilan bersosialisasi dengan lingkungan sekitarnya.

Yuliati (2015) menyatakan bahwa penerapan metode pembelajaran dengan menggunakan metode snowball throwing telah memperlihatkan peningkatan persentase ketuntasan hasil belajar siswa pada tahap siklus. Berdasarkan hasil tes awal dan akhir dari kedua siklus, maka dapat disimpulkan bahwa seluruh kegiatan perbaikan pengajaran ini semuanya telah menunjukkan keberhasilan dalam memberi pemahaman kepada para siswa secara tepat dan akurat.

Manfaat yang secara langsung terlihat adalah sedikit jumlah para siswa yang belajarnya tidak tuntas. Ini disebabkan karena penerapan metode pembelajaran dengan menggunakan model snowball throwing telah memperlihatkan peningkatan persentase siswa yang aktif dalam proses pembelajaran pada setiap siklus.

Pembelajaran tipe Snowball Throwing dapat meningkatkan hasil belajar. Gustomo (2015) Peningkatan hasil belajar menggunakan model pembelajaran kooperatif tipe Snowball Throwing lebih besar dibandingkan dengan hasil belajar menggunakan model pembelajaran konvensional. Hal ini sejalan dengan penelitian Ramlah (2017) yang menyatakan bahwa Berdasarkan hasil analisis dan pembahasan dapat disimpulkan bahwa penerapan metode pembelajaran kooperatif tipe snowball throwing dapat meningkatkan hasil belajar siswa. Keberhasilan ini disebabkan dengan penerapan metode pembelajaran kooperatif tipe snowball throwing siswa menjadi lebih aktif yang berarti siswa cenderung positif dalam mengikuti proses belajar mengajar yang diberikan oleh guru maupun dalam melakukan diskusi di dalam dan antar kelompoknya.

Pembelajaran akan menarik jika dipadukan dengan lagu daerah, lagu daerah merupakan lagu yang bersalan dari suatu wilayah atau daerah yang sudah ada sejak zaman dari dulu yang menjadi warisan budaya rakyat Indonesia yang patut dilestarikan. Adiozh 
(dalam Antari, 2016:3) menyatakan lagu daerah adalah lagu yang berasal dari suatu daerah tertentu dan menjadi populer dinyanyikan baik oleh rakyat tersebut mampun rakyat lainya Kegiatan pembelajaran dengan model pembelajaran kooperatif tipe snowball throwing berbantuan lagu daerah, siswa dibentuk menjadi beberapa kelompok dan membuat pertayaan dikertas yang digulung menyerupai bola, setelah selasai menggulung kertas. Kemudian, dilepar ke anggota kelompok lain dengan durasi waktu tertentu, saat proses pelemparan bola selasai siswa bersama anggota kelompoknya mendiskusikan jawaban dari pertayaan yang sudah didapatkan tadi. Saat proses membuat jawaban siswa dan kelompok membuat lirik lagu daerah untuk menyampaikan jawaban, saat menyampaikan jawaban siswa bersama kelompoknya bernyanyi lagu daerah dengan lirik lagu menggunakan jawaban dari pertayaan yang didapatkan. Sehingga, siswa menyapikan jawaban kepada kelompok lain menggunakan lagu daerah. Pembelajaran seperti ini akan membuat suasana kelas menyenangkan, siswa menjadi termotivasi dan siswa akan lebih mudah untuk mengingat jawaban dan materi pelajaran yang menyebabkan hasil belajar lebih optimal.

Pembelajaran konvensional yang dimaksud secara umum adalah pembelajaran yang menggunakan metode yang bisa dilakukan guru yaitu memberi materi melalui metode ceramah, latihan soal, kemudiam memberikan tugas. Dalam pembelajaran konvensioanl guru cenderung lebih aktif sebagai sumber informasi dan siswa cenderung pasif dalam menerima informasi tersebut.

Berdasarkan pemaparan dan pendapat ahli di atas, peneliti termotivasi untuk melakukan penelitian dengan judul Pengaruh Model Pembelajaran Kooperatif tipe Snowball Throwing berbantuan Lagu Daerah Terhadap Hasil Belajar IPA Siswa Kelas V Semster Genap di SDN Gugus VI Kecamatan Kintamani Kabupaten Bangli Tahun Pelajaran 2017/2018.

\section{Metode}

Penelitian ini dilaksanakan pada siswa kelas V di SDN Gugus VI kecamatan Kintamani Kabupaten Bangli. Penelitian ini tergolong penelitian eksperimen semu dengan desai penelitian Non-equvalen Post Test Only Control Group Desai. Presedir penelitian ini terdiri dari tiga tahap, yaitu tahap persiapan, pelaksanaan, dan pengakhiran eksperimen.

Populasi dalam penelitian seluruh siswa kelas V SDN di Gugus VI Kintamani dengan jumlah siswa 109 orang. Pemelihan sampel dalam penelitian ini menggunakan random sampling yang didapatkan hasilnya kelas SDN Desa Serai dan SDN Desa Awan sebagai kelas sampel yang berjumlan 50 orang.

Dalam penelitian ini dikumpul dengan beberapa pengumpulan data yang disesuaikan dengan tuntunan data masing-masing rumus permasalahan. Oleh karena itu data yang dikumpulan harus sesuai dengan kebutuhan untuk kelengkapan penelitian. Data yang dikumpulkan dalam penelitian ini adalah data hasil belajar IPA siswa kelas V. Metode yang digunakan untuk pengumpulan data adalah metode tes dengan istrumen digunakan tes objektif hasil belajar IPA dengan bentuk tes Objektif pilihan ganda dengan jumlah tes 30 butir soal. Tes akan diberikan setelah selesai kelas eksperimen selesai melakukan pembelajaran.

Analisis data yang digunakan dalam penelitian ini analisis stasistik deskripsi dengan menghitung nilai rata-rata, modus, median, skala lima, skor maksimal dan skor minimal. Dalam penelitian ini data disajikan dalam bentuk kurva polygon. Sebelum melakukan uji hipotesis dilakukan beberapa uji prasyarat yaitu. 1) Uji Normalitas Sembara Data menggunakan program SPSS 21.0 for Windows dengan kreteria pengujian data berdistribusi normal jika angka singnifikan (sig.) > 0,05. 2) Uji Homogenitas Varians menggunakan program SPSS 21.0 for Windows dengan kreteria data berdistribusi homogenitas jika angka singnifikan (sig.) $>0,05$. Setelah selesai melakukan uji prasyarat maka dilakukan dengan uji hipotesis dengan bantuan program SPSS 21.0 for Windows dengan kreteria jika $t_{\text {hitung }}>t_{\text {tabel }}$ dengan nilai (sig,) $<0,05$. Penelitian dilakukan di SDN Gugus VI Kecamatan Kintamani Kabupaten Bangli dengan rancangan penelitian pada kelas $\mathrm{V}$ semester genap tahun pelajaran 2017/2018. 


\section{Hasil dan Pembahasan}

Hasil post-test dari 28 siswa pada kelompok eksperimen diperoleh mean 19.82, median 20.5 dan modus 21.15, sebagai skor kelompok eksperimen cenderung tinggi. Data hasil post-test kelompok eksperimen disajikan dalam Gambar 1.

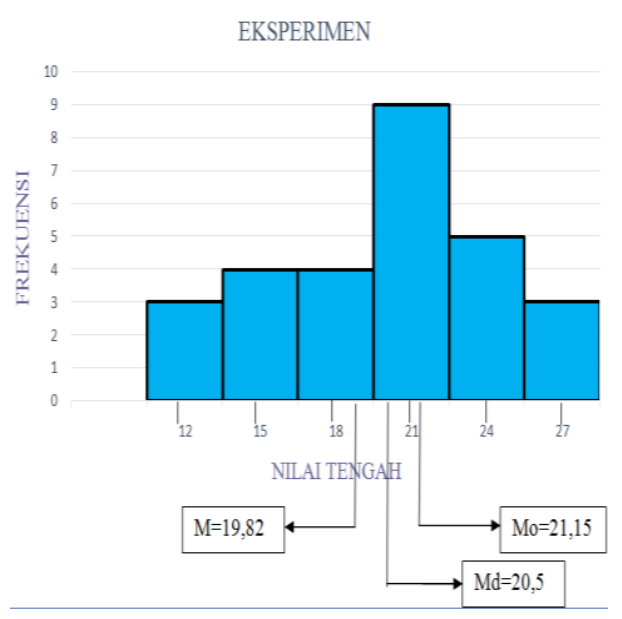

\section{Gambar 1. Grafik Histogram Skor Hasil Belajar IPA Kelompok Eksperimen}

Berdasarkangrafik Histogram di atas, sebagai skor cenderung tinggi. Berdasarkan perhitungan skala lima diperoleh skor rata-rata kelompok eksperimen dengan dibelajarkan model pembelajaran kooperatif tipe snowball throwing berbantuan lagu daerah adalah 19.82 termasuk katagori tinggi.

Hasil post-test dari 22 siswa pada kelompok kontrol diperoleh mean 16.09, median 16.00 dan modus 15.78, berarti sebagai skor kelompok kontrol cenderung sedang. Data hasil post-test kelompok kontrol disajikan dalam Gambar 2.

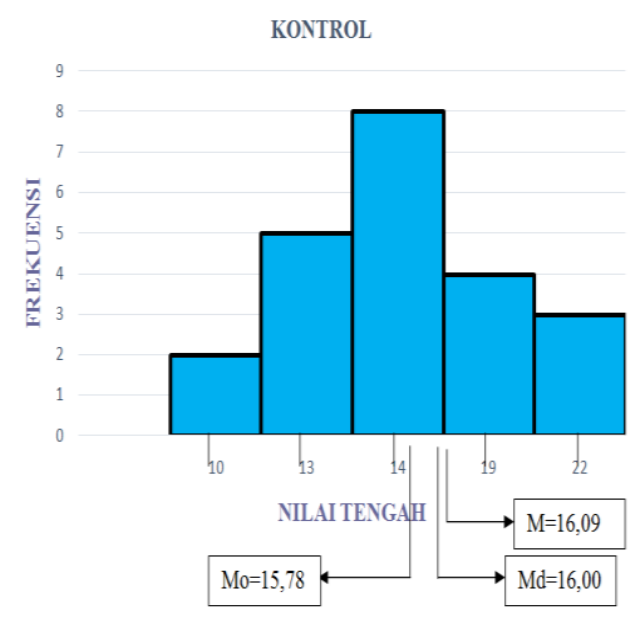

Gambar 2. Grafik Histogram Skor Hasil Belajar IPA Kelompok Kontrol.

Berdasrkan grafik Histogram di atas, sebagai skor cenderung sedang. Berdasarkan perhitungan skala lima diperoleh skor rata-rata kelompok kotrol dengan dibelajarkan pembelajaran konvensioan adalah 16.09 yang termasuk dalam katagori sedang. Hasil analisis data yang dilakukan, disajikan rakapitulasi data hasil belajar IPA siswa kelompok eksperimen dan kelompok kotrol pada table 1. 
Tabel 1. Rekapitulasi Hasil Perhitungan Data Hasil Belajar IPA.

\begin{tabular}{cccc}
\hline Kelompok & Mean & Median & Modus \\
\hline Eksperimen & 19,82 & 20,5 & 21,15 \\
Kontrol & 16,09 & 16,00 & 15,78 \\
\hline
\end{tabular}

Uji normalitas data dilakukan terhadap hasil belajar IPA pada kelompok eksperimen dan kelompok kontrol. Uji normalitas data dilakukan dengan bantuan SPSS-21.0 for windows uji satistik Kolmogrov-Smirnov pada taraf signifikan yang dihasilkan lebih besar dari 0.05 . Uji ini dilakukan pada data post-test kelompok eksperimen dan kelompok kontrol disajikan pada Table 2.

Tebel 2.Tests of Normality

\begin{tabular}{lllll}
\hline & & \multicolumn{3}{c}{ Kolmogorov-Smirnov $^{\mathrm{a}}$} \\
Kelompok & & Statistic & $\mathrm{df}$ & Sig. \\
\hline Hasil Belajar IPA & Eksperimen & .123 & 28 & $.200^{*}$ \\
& Kontrol & .094 & 22 & $.200^{\star}$ \\
a. Lilliefors Significance Correction & & & \\
\hline
\end{tabular}

Berdasarkan hasil uji normalitas data dengan teknik Kolomogrov-Smirnov diperoleh nilai kelompok ekeperimen dan kelompok kotrol adalah 0.200 , karena data yang dihasilkan lebih besar dari $0.05 \quad(0.200>0.05)$. Maka dapat disimpulkan semua sembara data bersdtribusi normal.

Uji Homogentitas Varians

Uji homogenitas varians dilakukan dengan menggunkan program SPSS-21.0 for windows pada taraf signigikan yang dihasilkan lebih besar dari 0.05 . uji homogentitas menggunakan test of homogeneity of variance. Data dapat diliahat pada Table 3 berikut.

Table 3. Ringkasan Hasil Uji Homogenitas Varians

\begin{tabular}{|c|c|c|c|c|c|c|}
\hline \multicolumn{7}{|c|}{ Test of Homogeneity of Variance } \\
\hline & & & Levene Statistic & $\mathrm{df} 1$ & $\mathrm{df} 2$ & Sig. \\
\hline Hasil & Belajar & Based on Mean & 1.288 & 1 & 48 & .262 \\
\hline IPA & & Based on Median & 1.144 & 1 & 48 & .290 \\
\hline
\end{tabular}

Dengan statistik yang didasarkan pada rata-rata (Bese on Mean) yang diperoleh nilai signifikan sebesar 0.262. Hasil analisis menunjukan banhwa nilai signifikan yang diperoleh lebih besar dari 0.05 (0.262>0.05). Dengan demikian dapat dismpulkan bahwa variable hasil belajar adalah homogent. Setelah semua data sudah normalitas dan homegent maka dilanjutkan uji hipotesis.

Uji Hipotesis

Pengeujian hipotesis tersebut dilakukan dengan menggunkan uji-t sampel independen (tidak berkorelasi) dengan kreteria $\mathrm{H}_{0}$ ditolak jika $t_{\text {hitung }}>t_{\text {tabel }}$ dan $\mathrm{H}_{0}$ diterima jika $t_{\text {hitung }}<t_{\text {tabel }}$. Uji hipotesis menggunakan program SPSS0-21.0 for windowas disajikan pada Tabel 4 
Tabel 4. Ringkasan Hipotesisi

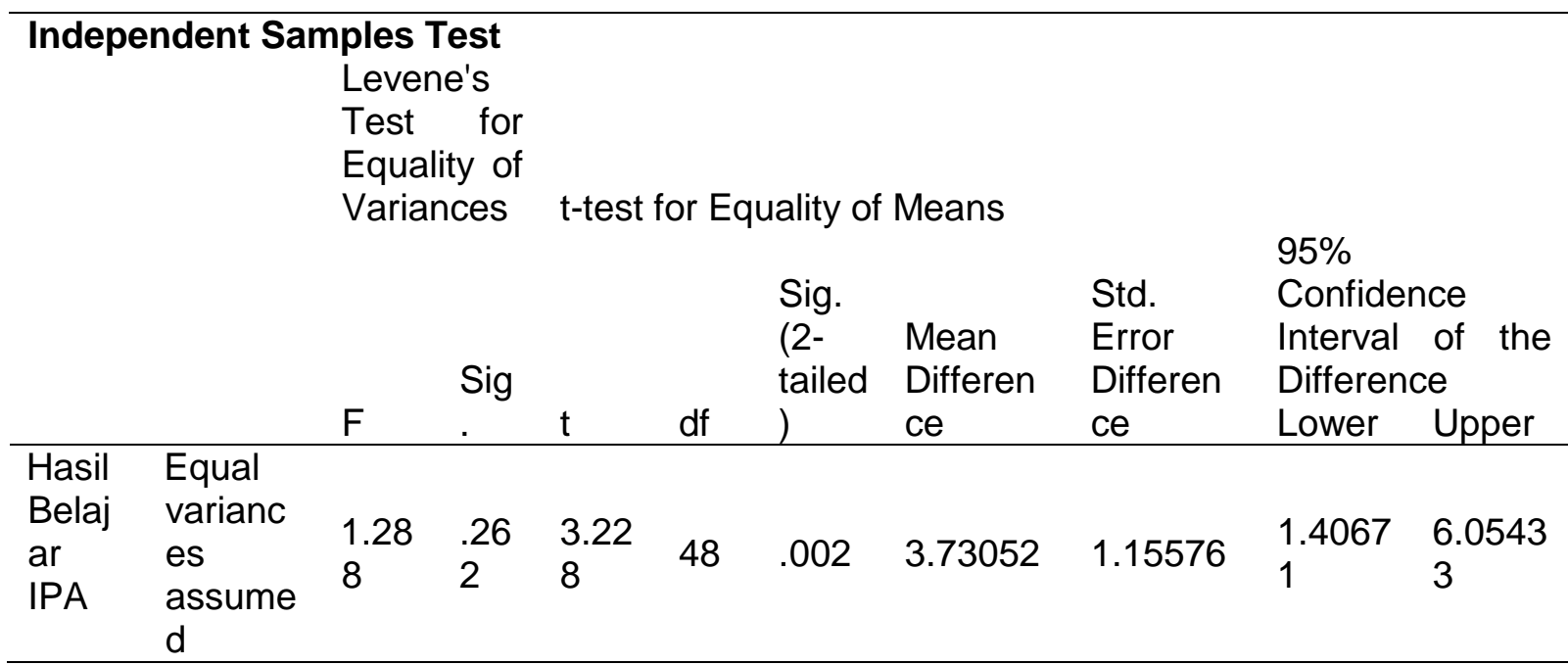

Berdasarkan analisis data menggunakan uji-t, diketahui $\mathrm{t}_{\text {hitung }}=3.228$ dan $\mathrm{t}_{\text {tabe }} \mathrm{l}(\mathrm{db}=48$ dan taraf signifikan $5 \%)=2.000$. Hasil perhitungan tersebut menunjukan $t_{\text {hitung }}$ lebih besar dari $t_{\text {tabel }}(3.228>2.000)$, dengan nilai sig $0.02<0.05$ sehingga hasil penelitian adalah signifikan. Berdasarkan analisis data tersebut, berarti terdapat perbedaan yang signifikan hasil belajar IPA antara siswa yang dibelajarkan dengan model pembelajaran kooperatif tipe snowball throwing berbantuan lagu daerah dengan siswa yang dibelajarkan pembelajaran konvensional pada kelas V di SDN Gugus VI Kecamatan Kintamani Kabupaten Bangli Tahun Pelajaran 2017/2018. Dengan demikian, model pembelajaran kooperatif tipe snowball throwing berbantuan lagu daerah berpengaruh positif terhadap hasil belajar IPA siswa.

Berdasrkan deskripsi data hasil penelitian, hasil belajar IPA siswa kelas eksperimen lebih tinggi dibandingkan siswa kelas kontrol. Tinjauan ini didasarkan atas análisis data, diketahui rata-rata (mean) hasil belajar IPA siswa kelompok eksperimen dengan menggunakan model pembelajaran kooperatif tipe snowball throwing berbantuan lagu saerah adalah 19,82 (katagori tinggi). Sedangkan hasil belajar IPA siswa kelompok kontrol dengan menggunakan pembelajaran konvensional adalah 16,09 (katagori sedang). Skor hasil belajar IPA siswa kelompok eksperimen yang digambarkan dalam grafik histogram yang menunjukan bahwa sebagai besar skor cenderung tinggi. Sedangkan skor hasil belajar IPA kelompok kontrol yang digambarkan dalam grafik histogram yang menunjukan bahwa sebagai besar cenderung sedang. Sehingga dapat katakana bahawa model pembelajaraan kooperatif tipe snowball throwing berbantuan lagu daerah berpengaruh terhadap hasil belajar IPA siswa.

Berdasrkan analisis data menggunakan uji-t dengan program SPSS 21.0 for windows, ketehaui $t_{\text {hitung }}=3,228$ dan $t_{\text {tabel }}(\mathrm{db}=48$ dan taraf singginfikan $5 \%)=2,000$. Hasil perhitungan tersebut menunjukan bahwa $t_{\text {hitung }}$ lebih besar dari $t_{\text {tabel }}(3,228>2,000)$, dan nilai sig (2-tailed) $0,02<0,05$ sehingga hasil penelitian adalah signifikan. Berdasrkan hasil analisis data tersebut, terdapat perbedaan yang signifikan hasil belajar IPA antara kelompok siswa yang dibelajarkan dengan model pembelajaran kooperatif tipe snowball throwing berbantuan lagu daerah dengan kelompok siswa yang dibelajarkan dengan pembelajaran konvensional, disebebkan oleh sebagai berikut.

Pembelajaran menggunakan model pembelajaran kooperatif tipe snowball throwing berperan penting terhadap perbedaan yang terjadi. Dalam model pembelajaran kooperatif di dalam kelas siswa belajar secara berkelompok yang dibentuk secara hiterogen karena terdapat berbagai jenis siswa dengan tingkat kemampuan yang berbeda, perbedaan kemampuan yang dimiliki oleh masing-masing siswa akan menyababkan saling tukar informasi antara siswa yang lebih mampu dengan siswa yang kurang mampu. Kegiatan 
diskusi di dalam sebuah kelompok akan terjadi disaat proses pembelajaran berlangsung, siswa akan berdiskusi tentang materi pembelajaran. Hal tersebut diperjelas pada Gambar 3.

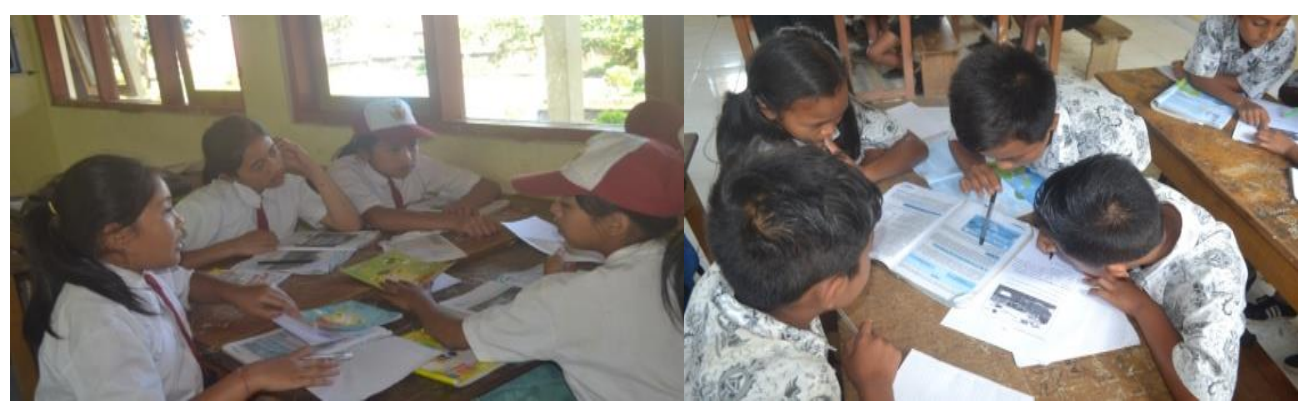

Gambar 3. Kegiatan Diskusi

Dalam sebuah kelompok semua anggota kelompok memahami materi yang dijelaska, ini akan membuat siswa berkerja sama saling berbagi ilmu dengan anggota kelompoknya. Hal ini sejalan dengan tujuan pembelajaran kooperatif yang dilihat dari teori kognitif menurut Vygotsky (dalam Cahyani, 2015) yang menyatakan "penyelesaian sebuah masalah dapat ditentukan melalui bantuan teman yang memiliki kemampuan yang lebih. Dalam diskusi kelompok siswa akan belajar satu sama lain mengenai materi, sehingga pemahaman yang lebih tingga akan muncul".

Temuan dalam peneliti ini juga didukung oleh penelitian yang dilaksanakan oleh Cahyadi (2017) "belajar secara kooperatif sangat cocok dan baik untuk menumbuhkan minat belajar siswa terutama bagi siswa yang memiliki kemampuan rendah atau kurang. Dalam pembelajaran kooperatif, siswa belajar dalam kelompok yang hiterogen sehingga dapat memotivasi siswa untuk saling membantu anggota kelompok untuk mencapai hasil belajar yang sesuai dengan tujuan pembelajaran yang diharapkan".

Belajar secara kelompok untuk saling berkerjasama dan dengan cara permainan melempar kertas yang dibentuk seperti bola dan didalam kertas berisi pertayaan merupakan pengertian dari model pembelajarn snowball throwing yaitu melepar bola pertayaan (bola salju) permainan pelemparan bola pertayaan ini membuat siswa merasa senang. Karena model pembelajaran kooperatif tipe snowball throwing membuat siswa lebih tanggap untuk menerima pesan yang diberikan dari kelompok lain, pada saat proses pembelajaran peran guru dalam model ini hanya memberi arahan awal atau topik pelajaran yang akan dilaksanakan dan salanjutnya menjaga ketertiban kelas. Siswa diberikan kesempatan lebih banyak untuk berpikir, berdiskusi, serta dapat mengembangkan kepemimpinan siswa dalam kelompok dan keterampilan membuat dan menjawab pertayaan maka siswa bersama kelompok berdiskusi untuk membuat pertayaan dan menjawab pertayaan dari anggota kelompok siswa yang lain. Oleh karena itu, setiap kelompok menyiapkan diri pada saat pelemparan bola pertayaan mereka harus siap menerima dan menjawab pertayaan dari kelompok siswa yang lain. Pada saat pelemparan bola yang berisi pertayaan (bola salju) antara kelompok dengan kelompok lain akan membuat siswa lebih semangat dalam mengikuti pelajaran.

Agar pembelajaran snowball throwing lebih menarik dan menyengkan maka dipadukan dengan bernyanyi lagu daerah. Guru dan siswa bersama-sama bernayanyi lagu daerah yang sudah siswa ketahui, selama kegiatan bernyanyi berlangsung proses pelemparan bola pertayaan akan terus berjalan, jika guru mengatakan berhenti bernyanyi maka proses pelemparan bola akan berhenti. Dalam proses pembuatan jawaban siswa dan kelompok membuat lirik lagu daerah untuk menyampaikan jawaban, menyampaikan jawaban siswa bersama kelompoknya bernyanyi lagu daerah dengan lirik lagu menggunakan jawaban dari pertayaan yang didapatkan. Siswa menyapikan jawaban kepada kelompok lain menggunakan lirik lagu daerah. Hal tersebut diperjelas pada Gambar 4. 


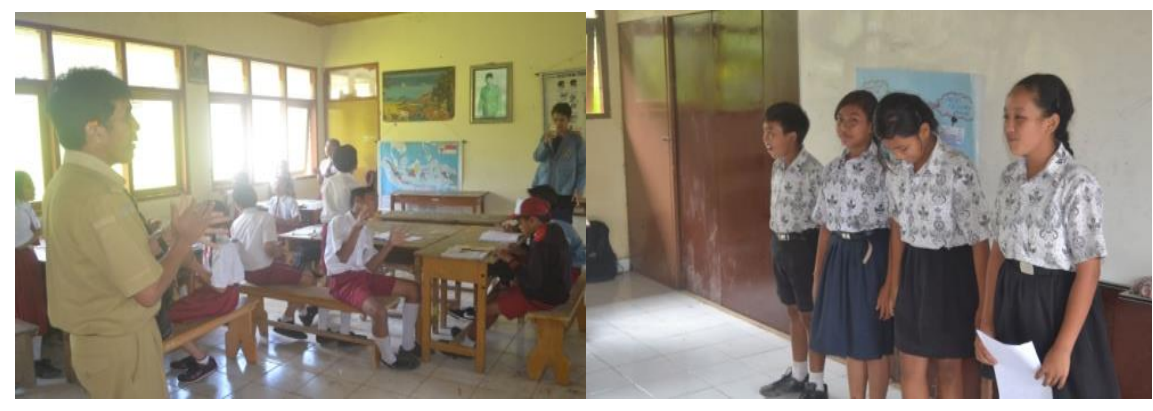

Gambar 4.Melempar Bola Pertayaan dengan Bernyanyi dan Menyampaikan Jawaban dengan Bernyanyi Didepan Kelas

Siswa salah menjawab pertayaan dari kelompok lain maka pertayaan akan di lempar ke anggota kelompok lain dengan menyampaikan jawaban sperti biasa tidak menggunakan lagu karena untuk mengefisienkan waktu pelajaran. Misalnya, siswa mendapatkan pertayan mengenai manfaat air, siswa bisa menjawab dengan lagu lirik daerah bibi yanu lamun payu luas manjus antenge tekekan, kata kunci dari lagu tersebut yaitu kata manjus yang artinya mandi, membersihkan badan, atau membasahi badan. Sehingga siswa dapat mengetahui kalau fungsi air sebagai pembasaha, mandi dan membersihkan. Pembelajaran seperti ini akan membuat suasana kelas menyenangkan, siswa menjadi termotivasi dan siswa akan lebih mudah menguasai materi dan konsep-konsep IPA lebih mudah dikuasai hal tersebut berdampak pada hasil belajar siswa yang baik.

Temuan dalam peneliti ini juga didukung oleh penelitian yang dilaksanakan oleh Kuniyanthi (2017) menyatakan "Model pembelajaran koopertaif tipe snowball throwing berbantuan lagu daerah dapat membuat siswa aktif, termotivasi, dan memapu berinteraksi dalam pembelajaran karena siswa diberikan kesempatan untuk membuat dan menjawab pertayaan dengan berdiskusi antara kelompok, serta dalam kegiatan bernyanyi membuat situasi dalam kelas lebih menyenangkan. Hal tersebut berdampak pada pengetahuan kognitif siswa.

Berbeda halnya dengan kelompok kontrol yang menerapkan pembelajaran konvensional. Pada saat proses pembelajara kegiatan pembelajaran lebih sering menggunakan metode cermah, pemberian tugas secara individu. Hal tersebut diperjelas pada Gambar 5.

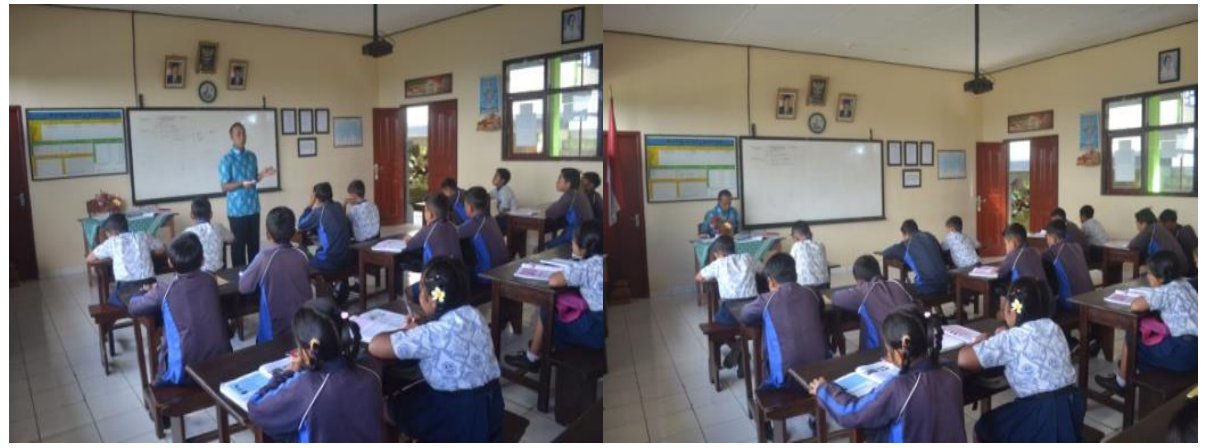

Gambar 5. Pembelajaran Menggunakan Metode Ceramah dan Pemberian Tugas

Dasmati (dalam Dhian, 2016) menyatakan "karakteristik anak sekolah dasar yaitu lebih senang bermain, bergerak, berkerja kelompok, dan senang merasakan atau melakukan sesuatu secara langsung". Tapi kenyataanya saat proses pembelajaran konvensional berlangsung, siswa hanya sebagai pendengar dan mengerjakan apa yang disuruh guru dengan demikian pembelajaran berpusat kepada guru dengan pembelajaran seperti ini siswa menjadi bosan sehingga berdampak pada hasil belajar siswa kurang baik. 
Temuan dalam peneliti ini juga didukung oleh penelitian yang dilaksanakan oleh Susanti (2014) "pembelajaran konvensional hanya diberikan materi pembelajaran dengan metode ceramah yang diselingi pembelajaran, kemudian diikuti dengan pemberian soal-soal evaluasi. Dengan pembelajaran seperti ini siswa tidak mempuyai kesempatan untuk berienteraksi dengan teman atau guru dengan baik, siswa hanya duduk dieam, mendengarkan, menirukan, menerima dan mengerjakan soal-soal evaluasi oleh guru. Hal ini menyebabkan hasil belajar IPA lebih rendah".

Berdasarkan pemaparan di atas, dapat disimpulkan bahwa terdapat perbedaan hasil belajar IPA yang signifikan antara kelompok siswa yang dibelajarkan dengan model pembelajaran kooperatif tipe snowball throwing berbatuan lagu daerah dengan kelompok siswa yang dibelajarkan dengan pembelajaran konvensional pada kelas V di SDN Gugus VI Kecamatan Kintamani Kabupaten Bangli Tahun Pelajaran 2017/201. Dengan demikian, model pembelajaran kooperatif tipe snowball throwing berbatuan lagu daerah berpengaruh positif terhadap hasil belajar IPA.

\section{Simpulan dan Saran}

Berdasarkan hasil penelitian dan pembahasan di atas, dapat disimpulkan sebagai berikut. Terdapat perbedaan hasil belajar IPA yang signifikan antara kelompok siswa yang dibelajarkan dengan model pembelajaran kooperatif tipe snowball throwing berbantuan lagu daerah dengan kelompok siswa yang dibelajaran dengan pembelajaran konvensional pada siswa kelas V di SDN Gugus VI kecamatan Kintamani Kabupaten Bangli Tahun Pelajaran $2017 / 2018$. Hasil perhitungan menunjukan bahwa $t_{\text {hitung }}$ lebih besar dari $t_{\text {tabel }}(3,228>2,000)$, dengan nilai sig 0,02 <0,05. Selain itu skor rata-rata kelompok eksperimen $=19,82>16,09$ skor rata-rata kelompok kontrol. Adanya perbedaan menunjukan bahwa penerapan model pembelajaran kooperatif tipe snowball throwing berbantuan lagu daerah berpengaruh positif terhadap hasil belajar IPA siswa.

Saran yang dapat disampaikan berdasarkan penelitian yang telah dilakukan adalah sebagai berikut.

1. Bagi guru

Agar lebih berupaya dalam menciptakan suasana kelas yang menyenangkan dan aktif dengan menerapkan model pembelajaran yang kooperatif, seperti model pembelajaran kooperatif tipe Snowball Throwing berbantuan Lagu Daerah untuk meningkatkan hasil belajar IPA siswa.

2. Bagi siswa

Dengan diterapkannya model pembelajaran kooperatif tipe Snowball Throwing berbantuan Lagu Daerah diharapkan mampu meningkatkan hasil belajar IPA siswa serta kualitas belajar.

3. Bagi peneliti lain

Hasil penelitian diatas menunjukan bahwa, diharapkan bagi peneliti lain yang berminat untuk mengadakan penelitian lebih lanjut tentang model pembelajaran kooperatif tipe Snowball Throwing berbantuan Lagu Daerah dalam bidang IPA maupun bidang ilmu lainnya, agar memperhatikan kendala-kendala yang dialami dalam penelitian ini sebagai bahan pertimbangan untuk perbaikan dan penyempurnaan penelitian yang akan dilaksanakan.

\section{Daftar Rujukan}

Akhiriyah, Dewi Yuni. 2011. Penerapan Model Pembelajaran Snowball Throwing untuk Meningkatkan Kualitas Pembelajaran IPS pada Siswa Kelas V SDN Kalibanteng Kidul 01 Kota Semarang. Jurnal Kependidikan Dasar. 1 (2) 206-219 
Antari, Luh Putu Sri Wahyu. 2016. Pengaruh Implementasi Model Pembelajaran Kooperatif Type Consept Song Berbasis Lagu Daerah Terhadap Hasil Belajar IPS Siswa Kelas III SD Gugus I Kecamatan Gianyar. e-Journal PGSD Universitas Pendidikan $\begin{array}{llllll}\text { Ganesha } & \text { Volume } & 4 & \text { No } & 1 & \text { Tahun } \\ & & \end{array}$ Tersedia.https://ejournal.undiksha.ac.id/index.php/JJPGSD/article/viewFile/7238/49 $\underline{43}$.

Arfini, Ni Kadek Buri. 2017. Pengaruh Model Pembelajaran Kooperatif Tipe Snowball Trhowing Berbantuan Gerak Literatis Terhadap Hasil Belajar IPA Siswa Kelas IV SD Di Gugus V Kecamatan Kubutambahan. e-Journal Mimbar PGSD Universitas Pendidikan Ganesha Volume:5 No: 2 Tahun 2017Tersediapadahttps://ejournal.undiksha.ac.id/index.php/JJPGSD/article/view/11 $\underline{034 / 7085}$

Cahyadi, I Gede. 2017. Pengaruh Model Pembelajaran Kooperatif Tipe Snowball Trhowing Berbantuan Media Video Clip Terhadap Hasil Belajar IPA Siswa Kelas V SD Di Gugus V Kecamatan Susut. e-Journal Mimbar PGSD Universitas Pendidikan Ganesha $\quad$ Volume:5 No: 2 Tahun 2017 Tersediapada.https://ejournal.undiksha.ac.id/index.php/JJPGSD/article/view/10773

Cahyani, I Gusti Agung Novia. 2015. Pengaruh Model Pembelajaran Kooperatif Tipe STAD Berbantuan Multimedia Pembelajaran Terhadap Hasil Belajar PKn. e-Journal Jurusan Teknolgi Pendidikan Universitas Pendidikan Ganesha Volume 3 No 1 Tahun 2015.

Dhian, Anggraini K. 2016. Identifikasi Kesulitan Belajar Siswa Kelas V SDN Sosrowijaya Kota Yognyakarta. Journal Pendidikan Guru Sekolah Dasar. Edisi 3 Tahun 2015.

Gustomo Ade. 2015. Penerapan Model Pembelajaran Snowball Throwing Untuk Meningkatkan Hasil Belajar Siswa pada Kompetensi Memperbaiki Unit Kopling dan Komponen-komponen Sistem Pengoperasian. Jurnal Pendidikan Teknik Mesin Vol. 15, No. 2, Desember 2015 (59-63)

Purbowo, Mashuri \& Hendikawati. 2012. Kefektifan Pembelajaran Snowball Throwing Berban-tuan Lembar Kegiatan Siswa. Unnes Jour-nal of Mathematics Education. 1 (1) $20-25$

Ramlah. 2017. Penerapan Metode Pembelajaran Kooperatif Tipe Snowball Throwing untuk Meningkatkan Hasil Belajar Fisika Pada Siswa Kelas Xii Sman 9 Pekanbaru. Jurnal Pendidikan dan Pengajaran Program Studi Pendidikan Guru Sekolah Dasar FKIP Universitas Riau Volume 1 Nomor 1 Juli 2017

Permendikbud. 2005. Satandar Proses Nomer 19 Tahun 2005 Tentang Standar Nasional Pendidikan. Jakarta: Kemendikbud.

Rusman. 2011. Model-Model Pembelajaran Mengembangkan Profesional Guru. Jakarta: PT Raja Grafindo Persada.

Shoimin, Aris. 2014. 68 Model Pembelajaran Inovatif dalam Kurikulum 2013 I.

Slavin, Robert E. 2008. Cooperative learning Teori, Riset dan Praktis.Bandung: Nusa Media

Sudana, Dewa Nyoman \& dkk. 2010. Pendidikan IPA SD.Undiksha: Singaraja. 
Susanti, Kd Ayu. 2014. Pengaruh Model Pembelajaran Kooperatif Tipe Snowball Trhowing Berbantuan Media Konkret Terhadap Hasil Belajar IPA Siswa Kelas V SD Di Gugus Gusti Ngurah Rai Denpasar. e-Journal Mimbar PGSD Universitas Pendidikan Ganesha $\quad$ Volume:2 $\quad$ No: 112014 Tersediapada.https://ejournal.undiksha.ac.id/index.php/JJPGSD/article/view/1924/1 $\underline{673}$

Tim Pustaka Yustisia. 2007. Panduan Lengkap KTSP (Kurikulum Tingkat Satuan Pendidikan). Yogyakarta:Pustaka Yustisia

UU RI NO.20 Undang-Undang Republik Indonesia Nomor 20 Tahun 2003 Tentang Sistem Pendidikan Nasional. Yaogyakarta: Ar-Ruzz Media

Yuliati.2015. Efektifitas Penggunaan Model Kooperatif Tipe Snowball Throwing Untuk Meningkatkan Hasil Belajar Siswa pada Materi Sistem Pertidaksamaan Linear di Kelas XI-IS-2 Sma Negeri 7 Banda Aceh. Jurnal Peluang, Volume 3, Nomor 2, April 2015, ISSN: 2302-5158

Zaini dkk. 2007. Strategi Pembelajaran Aktif. Yogyakarta: CTSD 